Mariusz Maziarz

Wrocław University of Economics

Faculty of Economic Sciences

e-mail: mariusz.maziarz@ue.wroc.pl

\title{
Przyczynowość w ekonomii. Najnowsze badania i nierozwiązane problemy*
}

\section{Causation in Economics. The Most Recent Analyses and the Unsolved Problems}

The main aim of my article is indicating the unsolved research problems connected to causation in the area of the philosophy of economics. First, I briefly define causation and discuss two most notable approaches, i.e. the realist theory of causation and the instrumentalist theory of causation. Second, I review the most recent researches focused on the problem of causation in economics. Third, I discuss a number of case studies. On the grounds of comparison of the research practice of economists and the current issues undertaken by the philosophers of economics, I conclude that there is a gap between the research practice and the normative methodological analyses and indicate the research questions that need to be answered.

Keywords: causation, the philosophy of economics, recent research, causation in economics

JEL Classification: A19, B41

\section{Uwagi wstępne}

Celem artykułu jest przedstawienie najnowszych światowych badań nad przyczynowością w filozofii ekonomii, porównanie ich z praktyką badawczą ekonomistów oraz sformułowanie problemów badawczych, które nie zostały dotąd rozwiązane.

\footnotetext{
* Badania, których wyniki opisano w niniejszym artykule, zostały sfinansowane przez Narodowe Centrum Nauki (grant nr 2015/19/N/HS1/01066). Autor serdecznie dziękuje za komentarze otrzymane od dra Bartosza Scheuera oraz dwóch anonimowych recenzentów czasopisma „Annales. Etyka w Życiu Gospodarczym".
} 
W pierwszej części podjęto próbę zwięzłej prezentacji pojęcia relacji przyczynowej (ontologia przyczynowości) oraz odpowiedzi na pytanie, w jaki sposób można ją poznać (epistemologia przyczynowości). Przyczynowość zostanie opisana w świetle dwóch najpopularniejszych paradygmatów filozofii nauki: realizmu naukowego oraz instrumentalizmu.

W drugiej części artykułu (w sekcji 3.) przedstawiono wyniki najnowszych badań poświęconych problemowi przyczynowości w filozofii ekonomii. Następnie (w sekcji 4.) dokonano analizy wybranych studiów przypadków mając na celu prezentację przykładów przemawiających na rzecz tezy, iż istnieje rozdźwięk pomiędzy kwestiami analizowanymi na gruncie filozofii i metodologii ekonomii, a problemami napotykanymi przez ekonomistów podczas prac badawczych. Zakończenie zawiera prezentację wniosków z porównania praktyki badawczej ekonomistów oraz problemów związanych z kwestiami ontologii i epistemologii przyczynowości podejmowanych we współczesnej filozofii ekonomii. Ponadto sformułowano problemy badawcze, które nie zostały dotąd podjęte w światowej literaturze przedmiotu, a ich analiza $\mathrm{z}$ perspektywy metodologicznej wydaje się niezbędna. Po pierwsze, przegląd literatury przedmiotu pozwolił zauważyć brak badań metodologicznych poświęconych opisowi metod rzeczywiście stosowanych przez ekonomistów. Po drugie, poza chlubnym wyjątkiem testów przyczynowości w sensie Grangera, w literaturze przedmiotu nie podjęto dotychczas badań nad założeniami filozoficznymi dotyczącymi rzeczywistości gospodarczej, a w szczególności charakteru relacji przyczynowych leżącymi u podstaw stosowanych metod badawczych oraz ich ugruntowaniu w filozoficznych teoriach przyczynowości. Po trzecie, współczesna refleksja filozofów ekonomii nad problemami ontologii i epistemologii przyczynowości we współczesnej ekonomii ma ograniczoną możliwość zastosowania przez ekonomistów w praktyce badawczej.

\section{Teoretyczne ujęcia problemu przyczynowości}

Mianem realizmu przyczynowego nazywa się pogląd, zgodnie z którym relacja przyczyna-skutek rzeczywiście istnieje w świecie, poza podmiotem poznającym. Taki sposób istnienia jest dobrze rozumiany przez jednego $\mathrm{z}$ bohaterów bajki napisanej przez Milne'go: na pytanie Kubusia Puchatka o biegun północny Krzyś odpowiada: To jest coś, co się odkrywa . Realiści (przyczynowi) twierdzą, że relacja przyczynowa pomiędzy X i Y istnieje wtedy i tylko wtedy, gdy istnieją mechanizmy przyczynowe łączące wspomniane X i Y. W jaki sposób należy rozumieć pojęcie mechanizmu przyczynowego w naukach społecznych? Little definiuje to pojęcie jako sekwencję zdarzeń, warunków i procesów prowadzacych od przyczyny do

\footnotetext{
${ }^{1}$ A. Milne, Kubuś Puchatek, Nasza Księgarnia, Warszawa 1988, s. 111. Cf. M. Maziarz, Spór o obiektywne istnienie obiektów teorii ekonomicznych. Argument na rzecz esencjalizmu, „Przegląd Prawniczy, Ekonomiczny i Społeczny” 2013, nr 4, s. 27-38.
} 
$s k u t k u^{2}$. Realizm przyczynowy postuluje, by empiryczne dowody istnienia zależności przyczynowej rozszerzono o analizę mechanizmu postulowanego związku pomiędzy przyczyną i skutkiem ${ }^{3}$.

Drugim z opozycyjnych sposobów rozumienia relacji przyczyna-skutek jest utożsamienie relacji przyczynowej z regularnością. Zwolennicy poglądów Hume'a, stojąc w opozycji do poglądu opisanego powyżej, uważają, że rzeczywistość nie ma charakteru przyczynowego. Świat zewnętrzny po prostu ,jest" ${ }^{4}$. W związku z tym relacje przyczynowe są przez nich utożsamiane z regularnościami empirycznymi, czyli korelacją, modelem lub grafem przyczynowym.

Warto podkreślić, że poniższy opis teoretycznych ujęć przyczynowości z pewnością nie wyczerpuje tematu, który jest bardzo szeroki z kilku powodów. Po pierwsze, filozofowie i naukowcy byli zainteresowani badaniem przyczynowości oraz relacji przyczynowych od początku istnienia samej filozofii ${ }^{5}$. Po drugie, żadna z wielu definicji tego pojęcia, które zostały zaproponowane na przestrzeni dziejów nie jest szeroko akceptowana ${ }^{6}$. Wykorzystanie do zbadania relacji przyczynowej pomiędzy wspólnotowością a wzrostem gospodarczym dwóch konkurujących ze sobą teorii przyczynowości można uzasadnić cytując Cartwright, filozofa nauki z London School of Economics, która wskazuje, że autor każdej definicji utrzymuje, ze jego propozycja jest informatywna ${ }^{7}$.

\subsection{Podejście realistyczne}

Podstawowym założeniem realizmu przyczynowego jest uznanie, że przyczynowość istnieje w rzeczywistości ${ }^{8}$, a relacje przyczynowe nie są jedynie iluzją obserwowaną przez obserwatora wynikłą z czasowego następstwa zdarzeń, jak uważał Hume. Takie ujęcie zjawiska przyczynowości przez realizm przyczynowy oznacza, że nie może ono zostać zredukowane do innych przejawów istnienia rzeczywistości, takich jak deterministyczna lub probabilistyczna regularność zachodzenia dwóch zjawisk.

\footnotetext{
${ }^{2}$ (...) a causal mechanism is a sequence of events, conditions, and processes leading from the explanans to the explanandum. D. Little, Varieties of Social Explanation: An Introduction to The Philosophy of Social Science, Westview Press, Boulder, Colorado 1991, s. 15.

${ }^{3}$ M. Lewis-Beck, The SAGE Encyclopedia of Social Science Research Methods, SAGE, Washington 2003, s. 100.

${ }^{4}$ J. Williamson, Probabilistic Theories of Causality [w:] The Oxford Handbook of Causation, red. H. Beebee i in., Oxford University Press 2009, s. 185-212.

${ }^{5}$ H. Beebee, Introduction [w:] The Oxford Handbook of Causation, red. H. Beebee i in., Oxford University Press, London 2009.

${ }^{6}$ C.W.J. Granger, Testing for Causality. A Personal Viewpoint, „Journal of Economic Dynamic and Control" 1980, vol. 2, nr 4, s. 329-352.

${ }^{7}$ Each author of any definition argues that his definition is informative. N. Cartwright, Where Is the Theory in Our ,, Theories” of Causality?, „The Journal of Philosophy” 2006, vol. 103, nr 2, s. 55-66.

${ }^{8}$ M. Esfeld, Causal realism [w:] The Oxford Handbook of Causation, red. H. Beebee i in., Oxford University Press, Oxford 2011.
} 
Oznacza to, że realizm przyczynowy zakłada istnienie w świecie zewnętrznym czegoś, co można nazwać relacją przyczynową, która jest niezależna od umysłu poznającego. Warto zwrócić tu uwagę na centralną rolę przyczynowości w rzeczywistości będącej przedmiotem badań naukowców, która - dla przykładu - dla Bhaskara stanowiła esencję, istotę badanych zjawisk ${ }^{9}$. Drugą istotną cechą relacji przyczynowej, zgodnie z prezentowanym tu poglądem, jest istnienie pewnego rodzaju konieczności, dla przykładu: wystąpienie zdarzenia A pociąga za sobą wystąpienie zdarzenia $\mathrm{B}^{10}$. Pogląd ten w ostatnim czasie uległ złagodzeniu ze względu na zwrot zainteresowania filozofów nauki z nauk ścisłych (takich jak fizyka, która operuje na deterministycznych prawach przyczynowych) do nauk społecznych, gdzie kwestię niezdeterminowania rozwiązano poprzez zmianę sposobu rozumienia praw przyczynowych; uznano, że obowiązują one w modelu oraz dodano przyrostek „ceteris paribus”, oznaczający prawdziwość zdania stwierdzającego istnienie relacji przyczynowej jedynie w przypadku, gdy inne czynniki pozostają niezmienione. $\mathrm{Z}$ drugiej strony, Cartwright opowiada się za rozumieniem praw przyczynowych w charakterze skłonności (ang. capacity). Dla przykładu, zgodnie z taką interpretacją prawo popytu wyraża skłonność do spadku zapotrzebowania na rozważane dobro, gdy jego cena rośnie ${ }^{11}$.

Czym jest owa konieczność lub skłonność? Glennan wskazuje, że odpowiedzią na powyższe pytanie jest wskazanie mechanizmu, czyli systemu lub procesu, który składa się z wielu części. Reakcje zachodzące pomiędzy częściami wchodzącymi w skład mechanizmu przyczyniają się do stałości i zachodzenia relacji pomiędzy analizowanymi zdarzeniami. Zgodnie z wnioskiem wyciągniętym przez Glennana na podstawie analizy badań filozoficznych poświęconych relacji przyczynowości, odkrycie mechanizmu jest złotym standardem, który umożliwia ustanowienie $i$ wyjaśnienie powiąań przyczynowych ${ }^{12}$.

Zgodnie z argumentacją przedstawioną przez Kistlera, odkrycie uniwersalnej zależności jest niewystarczające do stwierdzenia, że analizowana relacja ma charakter przyczynowy ${ }^{13}$. Wynika to $\mathrm{m}$. in. $\mathrm{z}$ faktu, że uniwersalne generalizacje moga być prawdziwe przypadkowo. W związku z tym, Kistler stwierdza, że poznanie prawa opisującego mechanizm oddziaływania na siebie dwóch zjawisk (zdarzeń) jest konieczne do stwierdzenia, że analizowany związek ma charakter przyczynowy ${ }^{14}$.

W praktyce badawczej odkrycie mechanizmu przyczynowego wyjaśniającego analizowane zjawisko sprowadza się do analizy niższych poziomów rzeczywistości ${ }^{15}$, tj. teorii opisujących bardziej szczegółowe zagadnienia. Dla przykładu, poznanie teorii grawitacji, czyli mechanizmu oddziaływania pomiędzy dwoma

\footnotetext{
${ }^{9}$ R. Bhaskar, A Realist Theory of Science, Verso, London 1997.

${ }^{10}$ A. Chakravartty, Causal Realism: Events and Processes, „Erkenntnis” 2014, nr 63, s. 7-31.

${ }^{11}$ N. Cartwright, Where Is the Theory..., op. cit.

${ }^{12}$ Discovering a mechanism is the gold standard for establishing and explaining causal connections.

S. Glennan, Mechanisms [w:] The Oxford Handbook of Causation, red. H. Beebee i in., Oxford University Press 2009.

${ }^{13}$ M. Kistler, Causation and Laws of Nature, Routledge, London 2006, s. 75-99.

${ }^{14}$ Ibidem.

${ }^{15}$ Ł. Hardt, Studia z realistycznej filozofii ekonomii, C.H. Beck, Warszawa 2013.
} 
ciałami pozwala na uznanie, że proces przyciągania ma charakter przyczynowy, a nie jest tzw. pseudoprocesem, jak w przypadku poruszania się cienia drzewa w ciągu dnia ${ }^{16}$.

Podsumowując, badanie zjawisk przyczynowych w świetle realistycznego podejścia można utożsamić $\mathrm{z}$ analizą mechanizmów zachodzących pomiędzy dwoma procesami. W przypadku, gdy analizowany związek może zostać opisany prawami dzięki poznaniu mechanizmów łączących zdarzenia A i B, można uznać, że relacja ma charakter przyczynowy.

\subsection{Podejście instrumentalistyczne}

Inni filozofowie zdecydowanie zaprzeczali realnemu istnieniu zależności przyczynowych. Wielu filozofów i naukowców żyjących w okresie, gdy pozytywizm logiczny był najbardziej poważaną filozofią nauki, wyznawali poglądy wyrażone później przez Bertranda Russella, który uznawał, że przyczynowość jest reliktem minionej ery, który przetrwał, podobnie jak monarchia, wyłącznie dlatego, że nie robi żadnej szkody ${ }^{17}$.

Jednym z najbardziej znanych sceptyków był David Hume. Ten osiemnastowieczny historyk, który zajmował się również filozofią oraz metodologią nauk społecznych wierzył, że ludzki umysł nie jest zdolny do poznania relacji przyczynowej. Zamiast obserwacji takiej relacji, można jedynie zobaczyć zdarzenie A oraz następujące po nim zdarzenie B. Hume (1739) uzasadniał swój pogląd tym, że obserwator może doświadczyć tylko jednego zjawiska w danym czasie. W związku z tymiż relacja pomiędzy przyczyną i skutkiem łączy dwa momenty kontinuum czasowego, jest ona niemożliwa do bezpośredniego poznania.

Hoover ilustruje analizę przeprowadzoną przez Hume'a przykładem gry w bilard: kula A uderza kulę B i powoduje jej ruch ${ }^{18}$. Jakie wnioski wyciąga osiemnastowieczny historyk i filozof z obserwacji takiego zdarzenia? Po pierwsze, przyczynowość ma charakter asymetryczny, co oznacza, że jeżeli A powoduje B, B nie powoduje A. Z takiej przesłanki Hume dedukował fakt, że skutek musi poprzedzać przyczynę w czasie. Po drugie, uważał on, iż przyczyny są efektywne, co oznacza, że należy rozróżnić przypadkową korelację od relacji przyczynowej, której cechą jest to, że pierwszy element relacji wywołuje skutek.

Sceptycyzm Hume'a przejawiał się w poglądzie, że stały związek pomiędzy przyczyną a skutkiem nie może zostać poznany w żaden inny sposób jak tylko przez indukcję na podstawie obserwacji zdarzeń w czasowej kolejności. W związku z tym, Hume uważał, iż mówienie o przyczynach jest raczej zwyczajem umysłu niż uzasadnionym logicznie zjawiskiem.

\footnotetext{
${ }^{16}$ M. Kistler, op. cit.

${ }^{17}$ A. Chakravartty, op. cit.

${ }^{18}$ K. Hoover, Causality in Economics and Econometrics [w:] New Palgrave Dictionary of Economics, Palgrave, London 2006.
} 
Pomimo popularyzacji jego poglądów, wielu ekonomistów klasycznych dążyło do prowadzenia analizy zjawisk gospodarczych w kategoriach przyczyn i skutków. Do najważniejszych należeli Ricardo i Mill ${ }^{19}$. Drugi z nich zaproponował pięć metod inferencji relacji przyczynowych z danych. Były to metody: zgody, różnicy, połączonej (lub podwójnej) zgody i różnicy, reszt, towarzyszenia ${ }^{20}$.

Metoda różnicy pozwala określić przyczynę badanego zdarzenia w przypadku, gdy obserwator ma do czynienia z dwiema sytuacjami: w pierwszym przypadku określony skutek miał miejsce, w drugim przypadku - nie. Jeżeli te sytuacje są podobne pod wszystkimi aspektami poza jednym czynnikiem, ten czynnik jest uznawany za przyczynę zdarzenia.

Pomimo istnienia w historii ekonomii różnych sposobów badania przyczynowości, współcześni ekonometrycy przywołują klasycznych filozofów, by uzasadnić opracowywane metody. Granger pisze, że z rozważań Hume'a można wyciągnąć konkluzywne wnioski i sformułować warunki, jakie musi spełnić relacja, by zasługiwać na miano przyczynowej ${ }^{21}$. Zgodnie $\mathrm{z}$ punktem widzenia autora definicji badanej relacji znanej pod nazwą przyczynowości w sensie Grangera, zależność przyczynowa charakteryzuje się dwiema cechami:

(1) przyczyna poprzedza efekt w czasie,

(2) przyczyna zawiera informację o skutku, która nie jest dostępna w szerokim zbiorze innych zmiennych.

Biorąc pod uwagę tradycję redukcjonistycznego podejścia do przyczynowości, która jest utożsamiana ze stałą relacją i następstwem czasowym, Wiener zaproponował pierwszą definicję przyczynowości, na podstawie której można opracować metody służące kwantytatywnej ocenie występowania takiej relacji:

Dla dwóch symultanicznie mierzonych sygnatów, jeżeli można przewidzieć pierwszy sygnat lepiej przy użyciu informacji o przeszłości drugiego z nich niż bez tej informacji, to uzasadnione jest nazwać drugi sygnat przyczyna pierwszego sygnatu $^{22}$.

$\mathrm{Na}$ tej podstawie Granger (1980) zaproponował definicję przyczynowości opartą na trzech aksjomatach. Po pierwsze, przeszłość i teraźniejszość mogą powodować przyszłość, ale odwrotna zależność jest niemożliwa. Po drugie, zbiór wszystkich istotnych informacji ( $\left.\Omega_{\mathrm{n}}\right)$ nie zawiera informacji zbędnej, tj. w przypadku, gdy pewne zmienne $\left(Z_{\mathrm{n}}\right)$ są ze sobą skorelowane deterministycznie, powinny zostać wyłączone z $\Omega_{\mathrm{n}}$. Po trzecie, wszystkie relacje przyczynowe pozostają stałe w czasie. Na tej podstawie Granger opracował własną definicję przyczynowości, którą przed-

\footnotetext{
${ }^{19}$ M. Maziarz, O wartości informacyjnej testów przyczynowości w sensie Grangera, „Optimum. Studia Ekonomiczne" 2015, vol. 74, nr 2, s. 152-170.

${ }^{20}$ J.S. Mill, Zasady ekonomii politycznej, thum. E. Taylor, Polskie Wydawnictwo Naukowe, Warszawa 1966.

${ }^{21}$ C.W.J. Granger, Forecasting [w:] Philosophy of Economics, red. U. Mäki, Elsevier, Helsinki 2012.

${ }^{22}$ For two simultaneously measured signals, if we can predict the first signal better by using the past information from the second one than by using the information without it, then we call the second signal causal to the first one. M. Wiener, The Theory of Prediction [w:] Modern Mathematics for Engineers, McGraw-Hill, New York 1956, s. 165-183.
} 
stawiono poniżej. Aby można było ją zastosować w procesie ekonometrycznego testowania w analizie szeregu czasowego, należy przyjąć upraszczające założenie, że ' $\Omega_{t}$ oznacza wyłącznie zmienne istotne:

$$
\begin{gathered}
Y_{\mathrm{n}} \text { powoduje } \mathrm{X}_{\mathrm{n}+1} \text { wtedy i tylko wtedy, gdy: } \\
P\left(\left.X_{n+1} \in A\right|^{\prime} \Omega_{n}\right) \neq P\left(\left.X_{n+1} \in A\right|^{\prime} \Omega_{n}-Y_{n}\right) \text { dla jakiegoś A } \\
X_{t}, Y_{t}-\text { zmienne podejrzewane o bycie przyczyną i skutkiem } \\
\text { ' } \Omega_{t} \text { - cała wiedza dostępna w świecie w czasie t. }
\end{gathered}
$$

Warto podkreślić, iż testy przyczynowości w sensie Grangera są jedyną metodą, której inspiracje i założenia filozoficzne zostały zbadane. W dalszej części artykułu zostaną omówione obszary najnowszych badań w dziedzinie filozofii ekonomii poświęconych problemowi przyczynowości oraz, na podstawie porównania z wybranymi badaniami ekonomicznymi, wskazane zostaną dotychczas nierozwiązane problemy badawcze.

\section{Badania nad przyczynowością we wspólczesnej filozofii ekonomii}

Na podstawie przeglądu literatury można sformułować wniosek, iż we współczesnej metodologii ekonomii brakuje deskryptywnych ujęć metod stosowanych obecnie przez ekonomistów do uzasadniania wniosków stwierdzających istnienie relacji przyczynowych w rzeczywistości gospodarczej. Dotychczas nie dociekano jakie koncepcje i założenia filozoficzne leżą u podstaw tych metod. Jednym z nielicznych wyjątków są statystyczne testy przyczynowości w sensie Grangera ${ }^{23}$. Dotychczas nie przeprowadzono również systematycznych badań metodologii wykorzystywanej współcześnie przez ekonomistów, by odpowiedzieć na przedstawione powyżej pytania, mimo iż w literaturze obecne są analizy dotyczące praktyki badania przyczynowości w innych dziedzinach wiedzy. Dla przykładu, Shadish, Cook i Campbell przedstawili teorię generalizacji przyczynowych ugruntowaną w analizie metodologicznej rzeczywistych działań podejmowanych przez fizyków, chemików i biologów ${ }^{24}$. Podobnie Woodward, posługując się studiami przypadków zaczerpniętymi z nauk społecznych oraz przeglądem literatury metodologicznej, stwierdził, że przyczynowość jest przez badaczy społecznych rozumiana jako relacja niezmienna w przypadku interwencji ${ }^{25}$.

Metodologowie oraz filozofowie ekonomii, w przeciwieństwie do badaczy innych dziedzin nauki, zajmują się przede wszystkim historycznym rozwojem rozumienia problemu przyczynowości i metodami poświęconymi jego poznaniu

\footnotetext{
${ }^{23}$ Cf. C.W.J. Granger, Testing for Causality..., op. cit.; idem, Investigating causal relations by econometric models and cross-spectral methods, ,Econometrica” 1969, vol. 37, nr 3, s. 424-438.

${ }^{24}$ W. Shadish, Th. Cook, Th. Campbell, Experimental and quasi-experimental designs for generalized causal inference, Wadsworth Cengage Learning, Levland 2002.

${ }^{25}$ J. Woodward, Making Things Happen: A Theory of Causal Explanation, Oxford University Press, Oxford 2003.
} 
stosowanymi przez ekonomistów lub analizami normatywnymi, które nie są ściśle związane z praktyką badawczą ekonomistów, co powoduje, iż nie stanowią ram teoretycznych umożliwiających prowadzenie bardziej owocnych analiz ekonomicznych lub formułowanie właściwszych zaleceń dla polityków gospodarczych.

Nawet artykuły mające na celu zaprezentowanie przeglądu metod poznania relacji przyczynowych stosowanych przez ekonomistów skupiają się na analizie poglądów filozofów ekonomii, przedstawieniu rysu historycznego i omówienia wybranych współczesnych metod, które nie są szeroko stosowane. Dla przykładu, LeRoy podkreśla istotę podejścia grafowo-teoretycznego, nie omawiając aktualnej praktyki badawczej ekonomistów ${ }^{26}$. Hoover przedstawia rozwój historyczny i uzasadnienie filozoficzne wybranych historycznych metod teoretycznych i ekonometrycznych, omawiając m.in. badania komisji Cowlesa i rozumienie przyczynowości przez Herberta Simona ${ }^{27}$. Popularne są też badania monograficzne analizujące epistemologię przyczynowości wybranego ekonomisty lub jednej szkoły myśli ekonomicznej. Ich przykładem może być praca Hammonda, który dokonał analizy rozumienia pojęcia przyczynowości i metodologii stosowanej przez Miltona Friedmana, twórcę monetaryzmu ${ }^{28}$. Podobnie uczynił Blaug, który w swej pracy poświęconej metodologii ekonomii zreferował rozumienie przyczynowości przez Johna Stuarta Milla (filozofa i ekonomisty) oraz innych filozofów przełomu XVIII i XIX wieku $^{29}$.

Do analiz normatywnych można zaliczyć głośne wśród metodologów ekonomii prace Cartwright, która dokonała filozoficznej analizy ontologii i epistemologii przyczynowości ${ }^{30}$. Filozof nauki z London School of Economics argumentowała, że dociekania o zależnościach przyczynowych mogą być prowadzone nie tylko za pomocą kontrolowanych doświadczeń o losowym doborze próby (ang. randomized controlled trials), ale również poprzez inne metody hipotetyczno-dedukcyjne (mając na myśli m.in. modele ekonometryczne, które umożliwiają zmierzenie średniego wpływu interwencji na zmienną zależną), a o wyborze konkretnej metody powinien decydować zakres i rodzaj wiedzy o analizowanym zjawisku ${ }^{31}$. Pearl zaprezentowała i zunifikowała cztery filozoficzne podejścia do przyczynowości (probabilistyczne, manipulacjonistyczne, kontrfaktualne i strukturalne), konstruując metody matematyczne do analizy występowania przyczynowości w badanych zjawiskach ${ }^{32}$. Hoover zajmował się problemem przyczynowości w makroekonomii, jednak analizował nie praktykę ekonomistów, lecz badania metodologiczne poświęcone temu

\footnotetext{
${ }^{26}$ S. LeRoy, Causality in Economics, LSE Centre for Philosophy of Natural and Social Science, Technical Report 20/04, „Causality: Metaphysics and Methods” 2004.

${ }^{27}$ K. Hoover, Causality in Economics..., op. cit.

${ }^{28}$ D. Hammond, Theory and Measurement: Causality Issues in Milton Friedman's Monetary Economics, Cambridge University Press, Cambridge 2005.

${ }^{29}$ M. Blaug, The methodology of economics. Or how economists explain, Cambridge University Press, Cambridge 1992.

${ }^{30}$ N. Cartwright, Nature's Capacities and Their Measurement, Oxford University Press, Oxford 1989; eadem, Are RCTs the Gold Standard?, „BioSocieties” 2007, vol. 2, s. 11-20.

${ }^{31}$ Eadem, Hunting Causes and Using Them: Approaches in Philosophy and Economics, Cambridge University Press, Cambridge 2007.

32 J. Pearl, Causality: Models, Reasoning and Inference, Cambridge University Press, Cambridge 2009.
} 
problemowi ${ }^{33}$. Wyjątkami od przedstawionej powyżej systematyzacji badań metodologicznych nad rozumieniem i wnioskowaniem przyczynowym w ekonomii są artykuły poświęcone tym zagadnieniom w ekonomii behawioralnej ${ }^{34}$, chociaż także na tym gruncie dominuje podejście normatywne, tj. formułowanie zaleceń zwiększenia roli eksperymentów w metodologii ekonomii ${ }^{35}$.

W okresie ostatnich kilku lat nastąpił istotny wzrost zainteresowania problemem przyczynowości, o czym świadczy wzrost liczby artykułów publikowanych w najważniejszych czasopismach poświęconych problemom filozofii ekonomii (m.in. „Economics and Philosophy”, „Journal of Economic Methodology”, „Economics, Politics”, „Philosophy and Economics”). Jednakże większość z najnowszych prac zawiera normatywne analizy, które charakteryzują się ograniczoną możliwością aplikacji do praktyki badawczej ekonomistów. Grüne-Yanoff, będąc (podobnie jak większość filozofów ekonomii) realistą naukowym, argumentuje, że uzasadnienie decyzji o podjęciu interwencji gospodarczej jest właściwe tylko wtedy, gdy odwołuje się do mechanizmów przyczynowych ${ }^{36}$. Do nurtu normatywnych ujęć problemu przyczynowości w metodologii ekonomii należą również dociekania LeRoya, który rozważał jakie cechy musi posiadać model teoretyczny, by umożliwiać dedukcyjne poznanie relacji niezmiennych pod wpływem interwencji (ang. implementation-neutral causation) ${ }^{37}$. Wśród badań nad epistemologią przyczynowości z ostatnich lat pozytywnie wyróżnia się artykuł Cleveau i Mireles-Flores (2014), którzy próbują odpowiedzieć na pytanie o rozumienie pojęcia przyczynowości przez ekonomistów na podstawie analizy metodologicznej badania OECD (1994) na temat przyczyn bezrobocia ${ }^{38}$. Autorzy stwierdzają, że ekonomiści rzadko wyrażają explicite, którą z filozoficznych teorii przyczynowości uważają za prawdziwą i prezentują punkt widzenia, iż pytanie o adekwatność m.in. teorii regularności, teorii probabilistycznej, teorii kontrfaktualnej, teorii procesu, czy teorii manipulacjonistycznej pozostaje otwarte ${ }^{39}$.

\section{Praktyka badawcza ekonomistów}

Potrzebę prowadzenia badań nad epistemologią przyczynowości we współczesnych badaniach ekonomicznych podkreśla obserwacja praktyki ekonomistów oraz brak takich analiz w dotychczasowej filozofii ekonomii. Po pierwsze, we współczesnych badaniach

\footnotetext{
${ }^{33}$ K. Hoover, Causality in Macroeconomics, Cambridge University Press, Cambridge 2001.

${ }^{34} \mathrm{~Np}$. G. Loewenstein, Experimental Economics from the Vantage-point of Behavioural Economics, „The Economic Journal” 1999, vol. 109, nr 453, s. 25-34.

${ }^{35} \mathrm{~Np}$. G. Harrison, J. List, Field experiments, „Journal of Economic Literature” 2004, vol. 12, nr 1, s. $1009-1055$.

${ }^{36}$ T. Grüne-Yanoff, Why behavioural policy needs mechanistic evidence, „Economics and Philosophy” 2015, vol. 32, nr 3, s. 1-21.

${ }^{37}$ S. LeRoy, Implementation-Neutral Causation, „Economics and Philosophy” 2015, vol. 32, nr 1, s. 121-142, doi: 10.1017/S0266267115000280.

${ }^{38}$ F. Claveau, L. Mireles-Flores, On the Meaning of Causal Generalisations in Policy-oriented Economic Research, „International Studies in the Philosophy of Science” 2014, vol. 28, nr 4, s. 397-416.

${ }^{39}$ Ibidem.
} 
ekonomicznych można zaobserwować pluralizm metodologiczny. Dotychczas ekonomia nie wypracowała jednorodnej metodologii, a konkurencyjne szkoły myśli (paradygmaty badawcze) przyczyniają się do sytuacji, gdzie na podstawie takich samych danych empirycznych ekonomiści dochodzą do odmiennych konkluzji o kierunku lub istnieniu zależności przyczynowej, co można zegzemplifikować sprzecznymi wynikami badań o relacji między bazą monetarną i wzrostem gospodarczym lub o hipotezie progu ${ }^{40}$. Po drugie, analiza praktyki badawczej ekonomistów wskazuje, że wyciągają oni wnioski o charakterze przyczynowym na podstawie przesłanek nieuzasadnionych z perspektywy współczesnej filozofii ekonomii.

Częste są przypadki stawiania konkluzji o przyczynowym charakterze relacji na podstawie obserwacji poprzedzania w czasie, korelacji lub różnicy wartości średnich w różnych podgrupach badanej populacji. Poniżej zostaną omówione dwa studia przypadków oparte na głośnych w ostatnich latach artykułach, których autorzy na podstawie poczynionych obserwacji ekonometrycznych wyciągają przeciwstawne wnioski. Warto podkreślić, iż wyniki badań zostały wykorzystane do uzasadnienia prowadzonej przez rządy państw polityki gospodarczej, co pozwala domniemywać, że zostały one zinterpretowane w kategoriach przyczynowych. Wykorzystanie omówionych poniżej badań do podejmowania decyzji o polityce gospodarczej potwierdza obserwację Woodwarda, iż naukowcy zainteresowani naukami społecznymi traktują przyczynowość instrumentalistycznie, nazywając tak związki stałe pomimo podejmowanych interwencji ${ }^{41}$.

Pierwsze studium przypadków zostanie oparte na głośnej w ostatnich latach sprawie Reinhart-Rogoffa ${ }^{42}$, która jest przez dotychczasowych komentatorów niewłaściwie zrozumiana. Mianowicie, to nie błąd podkreślany przez Herndona, Asha i Pollina ${ }^{43}$, lecz odmienne metody badawcze zastosowane przez Reinhart i Rogoffa (2010) spowodowały uzyskanie odmiennych rezultatów (por. punkt 4.1). Drugie studium przypadku zostanie oparte na badaniach poświęconych kwestii prawdziwości hipotezy ekspansywnych cięć budżetowych, gdzie podobnie jak we wcześniejszym przypadku, Guajardo, Leigh i Pescatori oraz Alesina i Ardagna dochodzą do odmiennych wniosków ${ }^{44}$.

Ponadto, analiza praktyki badawczej ekonomistów wskazuje, iż zdarzają się przypadki, gdy stosują oni metodologię ugruntowaną w fillozofii ekonomii w sposób niezalecany przez metodologów. Przykładem takiej sytuacji może być badanie Ma-

\footnotetext{
${ }^{40}$ J. Stock, M. Watson, Interpreting the evidence on money-income causality, ,Journal of Econometrics” 1989, vol. 40, nr 1, s. 161-181; M. Maziarz, The Reinhart-Rogoff controversy as an instance of 'emerging contrary result' phenomenon, ,Journal of Economic Methodology” 2017, 13 March, doi: 10.1080/ 1350178X.2017.1302598

${ }^{41}$ J. Woodward, op. cit.

${ }^{42}$ C. Reinhart, K. Rogoff, Growth in a Time of Debt, „American Economic Review” 2010, vol. 100, nr 2, s. $573-578$

${ }^{43}$ Th. Herndon, M. Ash, R. Pollin, Does high public debt consistently stifle economic growth? A critique of Reinhart and Rogoff, „Cambridge Journal of Economics” 2014, vol. 38, nr 2, s. 257-279.

${ }^{44}$ J. Guajardo, D. Leigh, A. Pescatori, Will it hurt? Macroeconomic effects of fiscal policy: evidence from industrial and developing countries [w:] World Economic Outlook, International Monetary Fund 2010, s. 93-124; A. Alesina, S. Ardagna, Large Changes in Fiscal Policy: Taxes Versus Spending, „NBER Working Papers” 2009, nr 15438.
} 
drak-Grochowskiej i Żurek, które zastosowały testy przyczynowości w sensie Grangera do analizy zależności pomiędzy szeregami czasowymi wariancji stóp zwrotu wybranych indeksów giełdowych, tj. do badania zjawiska, które, zgodnie z dotychczasową wiedzą teoretyczną, nie ma charakteru przyczynowego ${ }^{45}$. Warto zwrócić uwagę, iż autor metody sprzeciwił się takiemu zastosowaniu opracowanego testu przyczynowości, argumentując, iż może to prowadzić do niewłaściwych wniosków $^{46}$. Ponadto, praktykujący ekonomiści często skupiają się na jednej z metod (dedukcji teoretycznej lub ekonometrycznej analizie korelacji) wynikających z dwóch głównych ujęć filozoficznych problemu przyczynowości, co może również prowadzić do błędnych wniosków ${ }^{47}$.

\subsection{Sprawa Reinhart-Rogoffa}

Tzw. sprawa Reinhart-Rogoffa (the Reinhart-Rogoff affair) to określenie stosowane w odniesieniu do dyskusji wywołanej publikacją dwóch głośnych i wpływowych artykułów. Reinhart i Rogoff (2010), na podstawie stworzonej przez siebie historycznej bazy danych zawierającej około 3000 obserwacji poziomu współczynnika długu publicznego do PKB dla 44. krajów na przestrzeni blisko 200 lat, przedstawili wyniki wskazujące na istnienie progu w relacji pomiędzy wspomnianym wskaźnikiem a tempem rozwoju ekonomicznego ${ }^{48}$. Zgodnie ze sformułowaną w artykule Growth in a Time of Debt hipotezą progu, dług publiczny przewyższający poziom 90\% stosunku długu publicznego do PKB znacznie spowalnia wzrost gospodarczy.

Ich artykuł został skrytykowany przez Herndona, Asha i Pollina (2014), którzy, po nieudanych próbach replikacji i otrzymaniu arkusza kalkulacyjnego wykorzystanego przez Reinhart i Rogoffa do wykonywania obliczeń, wskazali trzy błędy: (1) niewłaściwą formułę $\mathrm{w}$ arkuszu kalkulacyjnym (która pominęła pięć pierwszych w porządku alfabetycznym krajów), (2) sposób liczenia średniej oraz (3) niewłączenie do bazy danych szeregu czasowego reprezentującego dane Nowej Zelandii.

Warto zwrócić uwagę, iż na miano błędu zasługuje jedynie błędna specyfikacja formuły sumującej komórki w arkuszu kalkulacyjnym, która doprowadziła do pominięcia średniego tempa rozwoju gospodarczego Australii, Austrii, Belgii, Kanady i Danii. Błąd nie wpłynął istotnie na estymowane wartości średnich (odnotowano różnice na poziomie od 0,1 do 0,3 punktu procentowego). Pozostałe dwa błędy wskazane przez Herndona, Asha i Pollina zasługują raczej na miano odmiennych

\footnotetext{
${ }^{45}$ M. Madrak-Grochowska, M. Żurek, Testowanie przyczynowości w wariancji między wybranymi indeksami rynków akcji na świecie, „Oeconomia Copernicana” 2011, vol. 2, nr 4, s. 5-25.

${ }^{46}$ C.W.J. Granger, Investigating causal relations by econometric models and cross-spectral methods, „Econometrica” 1969, vol. 37, nr 3, s. 424-438.

${ }^{47}$ M. Maziarz, Sposoby poznania relacji przyczynowych $w$ ekonomii. Argument na rzecz sceptycyzmu, „Kwartalnik Prawo-Społeczeństwo-Ekonomia” 2015, nr 2, s. 59-81.

${ }^{48}$ C. Reinhart, K. Rogoff, op. cit.
} 
wyborów metodologicznych, ponieważ istnieją argumenty uzasadniające niewłączenie szeregu czasowego długu Nowej Zelandii ${ }^{49}$ oraz wykorzystanie przez Reinhart i Rogoffa średniej ważonej ${ }^{50}$. Biorąc pod uwagę wpływ alternatywnych wyborów metodologicznych na oszacowanie tempa wzrostu gospodarczego w czterech grupach krajów/lat wydzielonych ze względu na zróżnicowanie wartości współczynnika długu publicznego do PKB, który jest znacznie większy niż rola wspomnianego powyżej błędu (por. Tabela 1), można stwierdzić, iż - w przeciwieństwie do dotychczasowych komentarzy obecnych w literaturze przedmiotu - zróżnicowanie wyników uzyskanych przez Reinhart i Rogoffa oraz Herndona, Asha i Pollina wynika nie z błędu, lecz z powzięcia odmiennych wyborów metodologicznych.

Tabela 1. Wartości średniego tempa wzrostu opublikowane przez Reinhart i Rogoffa (2010) oraz wartości uzyskane przez Herndona, Asha i Pollina (2014) podczas replikacji ich badania.

\begin{tabular}{|l|cccc|}
\hline & \multicolumn{5}{|c|}{ Kategoria: dlug publiczny do PKB } \\
Metoda & pon. 30\% & $30 \%-60 \%$ & $60 \%-90 \%$ & pow. 90\% \\
\hline $\begin{array}{l}\text { Wyniki skorygowane przez } \\
\text { Herndona, Asha i Pollina }\end{array}$ & 4,1 & 3,1 & 3,2 & 2,2 \\
\hline Elementy replikacji & \multicolumn{4}{c}{} \\
\hline Błąd w arkuszu kalkulacyjnym & 4,0 & 3,0 & 3,2 & 1,9 \\
Selektywny wybór lat & 4,2 & 3,1 & 3,2 & 1,9 \\
Średnia ważona & 4,0 & 3,0 & 3,0 & 1,9 \\
\hline Wyniki opublikowane przez & 4,1 & 2,8 & 2,8 & $-0,1$ \\
Reinhart i Rogoffa & &
\end{tabular}

Źródło: Th. Herndon, M. Ash, R. Pollin, Does high public debt consistently stifle economic growth? A critique of Reinhart and Rogoff, „Cambridge Journal of Economics” 2014, vol. 38, nr 2, s. 257-279.

Mimo iż Reinhart i Rogoff formułując hipotezę, że wysoki poziom dtugu do PKB (ponad 90\%) jest zwiazany z istotnie niższym poziomem wzrostu ${ }^{51}$ nie twierdzili, iż ich odkrycie ma charakter przyczynowy, jednak hipoteza progu (ang. the 90\%-threshold hypothesis) została zinterpretowana w ten sposób zarówno przez wielu ekonomistów akademickich, jak również przez polityków gospodarczych.

\footnotetext{
${ }^{49}$ W okresie prac Reinhart i Rogoffa nad artykułem dostępne były dwa oszacowania historycznych wartości nowozelandzkiego PKB, opracowane przez Angusa Maddisona (Agnus Maddison's Database) oraz nowozelandzki urząd statystyczny (New Zealand Historical Statistics).

${ }^{50}$ C. Reinhart, K. Rogoff, op. cit.

Wskazywana w literaturze przedmiotu autokorelacja oraz zjawisko nawisów długu (ang. debt overhangs) powodują, że wykorzystanie nieważonej średniej mogłoby prowadzić do uzyskania wyników wprowadzających w błąd. Y. Dafermos, The 'other half' of the public debt-economic growth relationship: a note on Reinhart and Rogoff, „European Journal of Economics and Economic Policies: Intervention” 2015, vol. 12, nr 1, s. 20-28; C. Reinhart, V. Reinhart, K. Rogoff, Debt Overhangs: Past and Present, „NBER Working Paper” 2012, nr 18015. Cf. M. Maziarz, It's All in the Eye..., op. cit.

${ }^{51}$ High debt/GDP levels (90 percent and above) are associated with notably lower growth outcomes. C. Reinhart, K. Rogoff, op. cit.
} 
Artykuł Growth in a Time of Debt został nazwany przez Krugmana jedną z najważniejszych analiz ekonomicznych ostatnich lat ${ }^{52}$. Wyniki uzyskane przez Reinhart i Rogoffa zasłużyły na taki tytuł dzięki temu, że ich publikacje ukazały się w okresie kryzysu finansowego, gdy kwestie wielkości długu publicznego i jego wpływu na wzrost gospodarczy zyskały na znaczeniu w związku ze zwiększeniem zadłużenia wielu krajów spowodowanym koniecznością sfinansowania planów ratunkowych dla upadających banków. Artykuł został zacytowany w republikańskim budżecie Stanów Zjednoczonych oraz przez Oliego Rehna, Komisarza ds. Gospodarki Unii Europejskiej. Ponadto, odwołało się do niego wielu polityków, włączając: Manuela Barroso, Angelę Merkel i Wolfganga Schaube ${ }^{53}$.

\subsection{Badania na temat hipotezy ekspansywnych cięć budżetowych}

Biorąc pod uwagę panujące obecnie wśród niektórych ekonomistów opinie o potrzebie zmniejszenia wielkości długu publicznego wielu państw świata, które, w odpowiedzi na kryzys finansowy, zdecydowały się na wdrożenie pakietów stymulacyjnych finansowanych sprzedażą obligacji, istotne jest pytanie: kiedy należy dokonać cięć budżetowych? Na pytanie czy lepsze dla średniego tempa rozwoju gospodarczego jest natychmiastowe ograniczenie długu publicznego, czy owocniejsze jest wstrzymanie się do czasu wyjścia kraju z recesji, próbują odpowiedzieć kliometrycy zajmujący się badaniem hipotezy ekspansywnych cięć budżetowych (ang. expansionary fiscal contraction hypothesis). Hipoteza została sformułowana 25 lat temu, jednak pytanie, czy cięcia budżetowe pozytywnie wpływają na tempo rozwoju ekonomicznego również w krótkim okresie, pozostaje otwarte.

Podobnie jak w przypadku omówionych powyżej przeciwstawnych wyników uzyskanych przez Reinhart i Rogoffa oraz Herndona, Asha i Pollina, również opinie ekonomistów na temat krótkookresowego wpływu cięć budżetowych na wzrost gospodarczy są podzielone. Keynesiści, wierząc w stałe ceny i płace w krótkim okresie, utrzymują, że cięcie budżetowe przyczynia się do krótkookresowej recesji (lub spowolnienia wzrostu) z powodu negatywnego wpływu na zagregowany popyt. $\mathrm{Z}$ drugiej strony, ekonomiści neoklasyczni argumentują, iż zmniejszenie deficytu może mieć pozytywny wpływ na tempo rozwoju gospodarczego nawet w krótkim okresie, ze względu na zwiększenie bogactwa konsumentów (poprzez zmniejszenie stóp podatkowych i wysokości premii za ryzyko) oraz zmniejszenie płac, co pozytywnie wpływa na konkurencyjność ${ }^{54}$.

$\mathrm{Z}$ powodu alternatywnych ujęć teoretycznych, badania nad hipotezą ekspansywnych cięć budżetowych skupiły się na analizie kliometrycznej wpływu ograniczania deficytu na wzrost gospodarczy w przeszłości. Pierwszym krokiem w takiej

\footnotetext{
${ }^{52}$ P. Krugman, How the case for austerity has crumbled, „The New York Review of Books” 2013, vol. 6.

${ }^{53}$ A. Botsch, Hypocritical Versus Hippocratic Economics [w:] Restoring Shared Prosperity. A Policy Agenda from Leading Keynesian Economists, red. Th. Palley, G. Horn, Boeckler, Dusseldorf 2013, s. 15-23; J. Smith, From Reinhart \& Rogoff's own data: UK GDP increased pace of economic growth when debt-to-GDP ratio was highest - and the debt ratio came down, „Prime Economics” 2013, April 20, http://www.primeeconomics.org/articles/1785 (data dostępu: 28.12.2015).

${ }^{54}$ A. Alesina, R. Perotti, Fiscal Adjustments in OECD Countries: Composition and Macroeconomic Effects, ,NBER Working Paper” 1996, nr 5730.
} 
analizie jest wskazanie lat, kiedy poszczególne kraje dokonywały cięć budżetowych. Guajardo, Leigh i Pescatori ${ }^{55}$ zdecydowali się dokonać tego na podstawie metodologii opracowanej przez Romera i Romer ${ }^{56}$, którzy oparli swoje badania na temat szoków fiskalnych na analizie źródeł deskryptywnych. Guajardo, Leigh i Pescatori, stosując podejście oparte na działaniach (ang. action-based approach) przeanalizowali OECD Economic Surveys, IMF Staff Reports, IMF Recent Economic Developments oraz inne raporty i rządowe dokumenty związane z polityką budżetową. Na podstawie analizy ekonometrycznej zmian tempa rozwoju gospodarczego w latach następujących po zidentyfikowanych cięciach budżetowych doszli oni do wniosku, że hipoteza ekspansywnych cięć budżetowych nie jest prawdziwa ${ }^{57}$.

Alesina i Ardagna, aby wskazać lata, w których dokonano cięć budżetowych, zdecydowali się przeanalizować zmiany w wielkości skorygowanego o zmiany cykliczne deficytu budżetowego (ang. cyclically adjusted primary balance, CAPB) ${ }^{58}$. Kliometrycy zastosowali metodę korekcji opracowaną przez Blancharda ${ }^{59}$. Po zidentyfikowaniu lat, gdy skorygowany deficyt budżetowy zmniejszył się o więcej niż 1,5\% wartości PKB i analizie zmian wielkości PKB w kolejnych latach, ekonomiści doszli do wniosku, iż hipoteza ekspansywnych cięć budżetowych jest prawdziwa.

Sprzeczność omówionych powyżej konkluzji wynika z wykorzystania odmiennych metod identyfikujących momenty przeprowadzania cięć budżetowych. Analiza lat wskazywanych w obu artykułach pokazuje, iż jedynie 30\% lat cięć budżetowych zostało zidentyfikowanych przez obie metody jednocześnie (por. Tabela 2). Podkreślenia wymaga fakt, iż obie metodologie są szeroko stosowane w literaturze przedmiotu oraz wspierane przez swoich zwolenników, co uniemożliwia dokonanie racjonalnego wyboru pomiędzy jedną z nich ${ }^{60}$.

Tabela 2. Porównanie lat wskazywanych jako okresy cięć budżetowych w wybranych krajach.

\begin{tabular}{|l|l|l|}
\hline \multicolumn{1}{|c|}{ Kraj } & \multicolumn{1}{|c|}{$\begin{array}{c}\text { Guajardo, Leigh i Pescatori } \\
(\mathbf{2 0 1 0})\end{array}$} & \multicolumn{1}{c|}{$\begin{array}{c}\text { Alesina i Ardagna } \\
(\mathbf{2 0 0 9 )})\end{array}$} \\
\hline Australia & $1986 ; 1987$ & $1987 ; 1988$ \\
\hline Austria & & $1984 ; 1996 ; 1997 ; 2005$ \\
\hline Belgia & $1982 ; 1983 ; 1987 ; 1993$ & $1982 ; 1984 ; 1987 ; 2006$ \\
\hline Dania & $1983 ; 1984 ; 1985 ; 1986$ & $1983 ; 1984 ; 1985 ; 1986 ; 2005$ \\
\hline Finlandia & $1992 ; 1993 ; 1994 ; 1996 ; 1997 ;$ & $1981 ; 1984 ; 1988 ; 1994 ; 1996 ;$ \\
& 1998 & $1998 ; 2000$ \\
\hline Francja & & 1996 \\
\hline
\end{tabular}

\footnotetext{
${ }_{55}^{5}$ J. Guajardo, D. Leigh, A. Pescatori, op. cit.

${ }^{56}$ Ch. Romer, D. Romer, The Macroeconomic Effects of Tax Changes: Estimates Based on a New Measure of Fiscal Shocks, „NBER Working Papers” 2007, nr 13264.

${ }^{57}$ J. Guajardo, D. Leigh, A. Pescatori, op. cit.

${ }^{58}$ A. Alesina, S. Ardagna, op. cit.

${ }^{59}$ O. Blanchard, Suggestions for a New Set of Fiscal Indicators, „OECD Economics Department Working Papers" 1990, nr 79.

${ }^{60}$ M. Maziarz, It's All in the Eye of Beholder, „Argumenta Oeconomica” (artykuł złożony do druku).
} 
PRZYCZYNOWOŚĆ W EKONOMII...

\begin{tabular}{|l|l|l|}
\hline \multicolumn{1}{|c|}{ Kraj } & \multicolumn{1}{|c|}{$\begin{array}{c}\text { Guajardo, Leigh i Pescatori } \\
(\mathbf{2 0 1 0})\end{array}$} & \multicolumn{1}{c|}{$\begin{array}{c}\text { Alesina i Ardagna } \\
(\mathbf{2 0 0 9 )}\end{array}$} \\
\hline Grecja & \multicolumn{1}{|c|}{$\begin{array}{l}1986 ; 1991 ; 1994 ; 1996 ; 2005 ; \\
2006\end{array}$} \\
\hline Hiszpania & & $1986 ; 1987 ; 1994 ; 1996$ \\
\hline Holandia & & $1983 ; 1988 ; 1991 ; 1993 ; 1996$ \\
\hline Irlandia & $1982 ; 1983 ; 1987 ; 1988 ; 2009$ & $1984 ; 1987 ; 1988 ; 1989 ; 2000$ \\
\hline Japonia & 1997 & $1984 ; 1999 ; 2001 ; 2006$ \\
\hline Kanada & & $\begin{array}{l}1981 ; 1986 ; 1987 ; 1995 ; 1996 ; \\
1997\end{array}$ \\
\hline Niemcy & & $1996 ; 2000$ \\
\hline Norwegia & & $\begin{array}{l}1980 ; 1983 ; 1989 ; 1996 ; 2000 ; \\
2004 ; 2005\end{array}$ \\
\hline Nowa Zelandia & & $1987 ; 1989 ; 1993 ; 1994 ; 2000$ \\
\hline Portugalia & $1983 ; 2002$ & $\begin{array}{l}1982 ; 1983 ; 1986 ; 1988 ; 1992 ; \\
1995 ; 2002 ; 2006\end{array}$ \\
\hline Stany Zjednoczone & 1991 & $1981 ; 1983 ; 1984 ; 1986 ; 1987 ;$ \\
\hline Szwecja & $1983 ; 1993 ; 1995 ; 1996 ; 1997$ & $1994 ; 1996 ; 1997 ; 2004$ \\
\hline Wielka Brytania & $1981 ; 1997$ & $\begin{array}{l}1982 ; 1988 ; 1996 ; 1997 ; 1998 ; \\
2000\end{array}$ \\
\hline Włochy & $1992 ; 1993 ; 1995 ; 1997$ & $\begin{array}{l}1980 ; 1982 ; 1990 ; 1991 ; 1992 ; \\
1997 ; 2007\end{array}$ \\
\hline
\end{tabular}

Źródło: M. Maziarz, It's All in the Eye of Beholder, „Argumenta Oeconomica” (artykuł złożony do druku).

Drugim istotnym podobieństwem obu studiów przypadków jest fakt, iż ekonomiści na podstawie analizy historycznych związków pomiędzy szeregami czasowymi formułują zalecenia dla polityki gospodarczej. Artykuł Guajardo, Leigh i Pescatori został opublikowany w raporcie Międzynarodowego Funduszu Walutowego World Economic Outlook poświęconego bieżącej sytuacji makroekonomicznej oraz sposobom przeciwdziałania kryzysowi. Autorzy explicite opowiadają się przeciw zaleceniom formułowanym w zakończeniu artykułu Alesiny i Ardagny, którzy doradzali natychmiastową redukcję wielkości deficytu budżetowego i długu publicznego ${ }^{61}$. Z drugiej strony, Guajardo, Leigh i Pescatori, na podstawie poczynionych obserwacji kliometrycznych, zalecają politykom gospodarczym wstrzymanie się od reform budżetowych do momentu wyjścia gospodarek z recesji ${ }^{62}$.

${ }^{61}$ J. Guajardo, D. Leigh, A. Pescatori, op. cit.

${ }^{62}$ Ibidem. 


\section{Zakończenie}

Rozdźwięk pomiędzy filozofią ekonomii a praktyką badawczą ekonomistów jest szczególnie silny w obszarze badań nad ontologią i epistemologią przyczynowości oraz relacjami przyczynowymi w gospodarce. Omówione powyżej studia przypadków pokazują, że ekonomiści formułują zalecenia dla polityków gospodarczych, tj. stwierdzają istnienie relacji przyczynowych na podstawie przesłanek, które - zgodnie ze współczesną filozofią ekonomii - nie są uzasadnione. Z drugiej strony, współcześni filozofowie specjalizujący się w zagadnieniach dotyczących ekonomii i nauk społecznych oraz metodologowie, na podstawie prowadzonych badań, wyciągają normatywne wnioski, które - ze względu na restrykcyjność - nie mogą być przestrzegane podczas prowadzenia badań przez ekonomistów.

Biorąc pod uwagę opinię McCloskey, która silnie oponowała przeciw formułowaniu na podstawie badań metodologicznych zasad ograniczających wolność i pomysłowość naukowców, zalecając jednocześnie filozofom nauki zajmowanie się analizami deskryptywnymi praktyki badawczej i sposobów uzasadniania swoich wyników ${ }^{63}$, oraz rozdźwięk pomiędzy omówionymi powyżej najnowszymi badaniami poświęconymi przyczynowości $\mathrm{w}$ filozofii ekonomii a metodami inferencji relacji przyczynowych przez ekonomistów w omówionych studiach przypadków, można sformułować problemy badawcze, które nie zostały dotychczas podjęte i wyczerpująco zanalizowane:

(1) Jakie metody badawcze stosują współcześnie ekonomiści do wnioskowania o relacjach przyczynowych?

(2) Jakie założenia filozoficzne leżą u podstaw tych metod?

(3) Które z filozoficznych teorii przyczynowości odzwierciedlają rozumienie tego terminu przez ekonomistów?

(4) Który z paradygmatów filozofii nauki najlepiej opisuje działania ekonomistów?

Rozwiązanie powyższych problemów badawczych poprzez systematyczne badania praktyki naukowej ekonomistów pozwoli zrozumieć metody badania relacji przyczynowych rzeczywiście stosowane w badaniach oraz ich ograniczenia. Ponadto, stosując - dla przykładu - podejście semantyki referencyjnej, tj. podejmując próbę odpowiedzi na pytanie jakie cechy musiałaby mieć rzeczywistość gospodarcza, czym musiałyby cechować się relacje przyczynowe, by zastosowane przez ekonomistów metody były właściwe, będzie możliwe sformułowanie wniosków o sposobach rozumienia przyczynowości przez ekonomistów oraz wskazanie tych paradygmatów filozofii nauki oraz filozoficznych teorii przyczynowości, które oferują największą adekwatność deskryptywną.

\footnotetext{
${ }^{63}$ D. McCloskey, Rhetoric of Economics, The University of Wisconsin Press, Wisconsin 1998.
} 


\section{Bibliografia}

Alesina A., S. Ardagna, Large Changes in Fiscal Policy: Taxes Versus Spending, „NBER Working Papers" 2009, nr 15438.

Alesina A., R. Perotti, Fiscal Adjustments in OECD Countries: Composition and Macroeconomic Effects, „NBER Working Paper” 1996, nr 5730.

Beebee H., Introduction [w:] The Oxford Handbook of Causation, red. H. Beebee i in., Oxford University Press, London 2009.

Bhaskar R., A Realist Theory of Science, Verso, London 1997.

Blanchard O., Suggestions for a New Set of Fiscal Indicators, „OECD Economics Department Working Papers" 1990, nr 79.

Blaug M., The methodology of economics. Or how economists explain, Cambridge University Press, Cambridge 1992.

Botsch A., Hypocritical Versus Hippocratic Economics [w:] Restoring Shared Prosperity. A Policy Agenda from Leading Keynesian Economists, red. Th. Palley, G. Horn, Boeckler, Dusseldorf 2013.

Cartwright N., Are RCTs the Gold Standard?, „BioSocieties” 2007, vol. 2, s. 11-20.

Cartwright N., Hunting Causes and Using Them: Approaches in Philosophy and Economics, Cambridge University Press, Cambridge 2007.

Cartwright N., Nature's Capacities and Their Measurement, Oxford University Press, Oxford 1989.

Cartwright N., Where Is the Theory in Our ,Theories” of Causality?, „The Journal of Philosophy" 2006, vol. 103, nr 2, s. 55-66.

Chakravartty A., Causal Realism: Events and Processes, „Erkenntnis” 2014, nr 63, s. 7-31.

Claveau F., L. Mireles-Flores, On the Meaning of Causal Generalisations in Policy-oriented Economic Research, „International Studies in the Philosophy of Science” 2014, vol. 28, nr 4, s. 397-416.

Dafermos Y., The 'other half' of the public debt-economic growth relationship: a note on Reinhart and Rogoff, „European Journal of Economics and Economic Policies: Intervention" 2015, vol. 12, nr 1, s. 20-28.

Esfeld M., Causal realism [w:] The Oxford Handbook of Causation, red. H. Beebee i in., Oxford University Press, Oxford 2011.

Glennan S., Mechanisms [w:] The Oxford Handbook of Causation, red. H. Beebee i in., Oxford University Press 2009.

Granger C.W.J., Investigating causal relations by econometric models and cross-spectral methods, „Econometrica” 1969, vol. 37, nr 3, s. 424-438.

Granger C.W.J., Forecasting [w:] Philosophy of Economics, red. U. Mäki, Elsevier, Helsinki 2012.

Granger C.W.J., Testing for Causality. A personal Viewpoint, „Journal of Economic Dynamic and Control" 1980, vol. 2, nr 4, s. 329-352.

Grüne-Yanoff T., Why Behavioral Policy Needs Mechanistic Evidence, „Economics and Philosophy" 2015, vol. 32, nr 3, s. 1-21. 
Guajardo J., D. Leigh, A. Pescatori, Will it hurt? Macroeconomic effects of fiscal policy: evidence from industrial and developing countries [w:] World Economic Outlook, International Monetary Fund 2010, s. 93-124.

Hammond D., Theory and Measurement: Causality Issues in Milton Friedman's Monetary Economics, Cambridge University Press, Cambridge 2005.

Hardt Ł., Studia z realistycznej filozofii ekonomii, C.H. Beck, Warszawa 2013.

Harrison G., J. List, Field experiments, „Journal of Economic Literature” 2004, vol. 12, nr 1, s. 1009-1055.

Herndon Th., M. Ash, R. Pollin, Does high public debt consistently stifle economic growth? A critique of Reinhart and Rogoff, „Cambridge Journal of Economics” 2014, vol. 38, nr 2, s. 257-279.

Hoover K., Causality in Economics and Econometrics [w:] New Palgrave Dictionary of Economics, Palgrave, London 2006.

Hoover K., Causality in Macroeconomics, Cambridge University Press, Cambridge 2001.

Kistler M., Causation and Laws of Nature, Routledge, London 2006.

Krugman P., How the case for austerity has crumbled, „The New York Review of Books” 2013, vol. 6 .

LeRoy S., Causality in Economics, LSE Centre for Philosophy of Natural and Social Science, Technical Report 20/04, „Causality: Metaphysics and Methods” 2004.

LeRoy S., Implementation-Neutral Causation, „Economics and Philosophy” 2015, vol. 32, nr 1, s. 121-142, doi: 10.1017/S0266267115000280.

Lewis-Beck M., The SAGE Encyclopedia of Social Science Research Methods, SAGE, Washington 2003.

Little D., Varieties of Social Explanation: An Introduction to The Philosophy of Social Science, Westview Press, Boulder, Colorado 1991.

Loewenstein G., Experimental Economics from the Vantage-point of Behavioural Economics, „The Economic Journal” 1999, vol. 109, nr 453, s. 25-34.

Madrak-Grochowska M., M. Żurek, Testowanie przyczynowości w wariancji między wybranymi indeksami rynków akcji na świecie, „Oeconomia Copernicana” 2011, vol. 2, nr 4, s. 5-25.

Maziarz M., The Reinhart-Rogoff controversy as an instance of 'emerging contrary result' phenomenon, ,Journal of Economic Methodology” 2017, 13 March, doi: 10.1080/ 1350178X.2017.1302598.

Maziarz M., It's All in the Eye of Beholder, „Argumenta Oeconomica” (artykuł złożony do druku).

Maziarz M., O wartości informacyjnej testów przyczynowości w sensie Grangera, „Optimum. Studia Ekonomiczne” 2015, vol. 74, nr 2, s. 152-170.

Maziarz M., Spór o obiektywne istnienie obiektów teorii ekonomicznych. Argument na rzecz esencjalizmu, „Przegląd Prawniczy, Ekonomiczny i Społeczny” 2013, nr 4, s. 27-38.

Maziarz M., Sposoby poznania relacji przyczynowych w ekonomii. Argument na rzecz sceptyсуzmu, „Kwartalnik Prawo-Społeczeństwo-Ekonomia” 2015, nr 2, s. 59-81.

McCloskey D., Rhetoric of Economics, The University of Wisconsin Press, Wisconsin 1998.

Mill J.S., Zasady ekonomii politycznej, thum. E. Taylor, Polskie Wydawnictwo Naukowe, Warszawa 1966. 
Milne A., Kubuś Puchatek, Nasza Księgarnia, Warszawa 1988.

OECD, Jobs Study: Evidence and Explanations, OECD Publishing, Paris 1994.

Pearl J., Causality: Models, Reasoning and Inference, Cambridge University Press, Cambridge 2009.

Reinhart C., K. Rogoff, Growth in a Time of Debt, „American Economic Review” 2010, vol. 100, nr 2, s. 573-578.

Reinhart C., V. Reinhart, K. Rogoff, Debt Overhangs: Past and Present, „NBER Working Paper" 2012, nr 18015.

Romer Ch., D. Romer, The Macroeconomic Effects of Tax Changes: Estimates Based on a New Measure of Fiscal Shocks, „NBER Working Papers” 2007, nr 13264.

Shadish W., Th. Cook, Th. Campbell, Experimental and quasi-experimental designs for generalized causal inference, Wadsworth Cengage Learning, Levland 2002.

Smith J., From Reinhart \& Rogoff's own data: UK GDP increased pace of economic growth when debt-to-GDP ratio was highest - and the debt ratio came down, „Prime Economics" 2013, April 20, http://www.primeeconomics.org/articles/1785.

Stock J., M. Watson, Interpreting the evidence on money-income causality, ,Journal of Econometrics" 1989, vol. 40, nr 1, s. 161-181.

Wiener M., The Theory of Prediction [w:] Modern Mathematics for Engineers, McGrawHill, New York 1956, s. 165-183.

Williamson J., Probabilistic Theories of Causality [w:] The Oxford Handbook of Causation, red. H. Beebee i in., Oxford University Press 2009, s. 185-212.

Woodward J., Making Things Happen: A Theory of Causal Explanation, Oxford University Press, Oxford 2003. 